ISSN: 2085-0344 (Print)

ISSN: 2503-1864 (Online)

Journal homepage: www.ejournal.almaata.ac.id/literasi

Journal Email: literasi_stia@yahoo.com

\title{
Peran Guru dalam Pembiasaan Sholat Berjamaah
}

\author{
Ratna Purwaningsih \\ Prodi PAI Universitas Alma Ata Yogyakarta
}

Lathifatul Izzah

Prodi PAI Universitas Alma Ata Yogyakarta, Email: izzahelmahdi@gmail.com

\begin{abstract}
Article is the result of field research (field research) using qualitative methods. This article tries to explain about the kind of worship prayer in congregation usually done in public madrasah tsanawiyah (MTS N) Galur Kulon Progo DIY, also will be to explain about the role of teachers in the habit of worship prayer in congregation for students in MTs N Galur Kulon Progo DIY. Thus the conclusion of this article mention that this type of regular daily prayers in congregation is held in the MTS $N$ is Dhuha prayer, prayer Dhuhr, and Friday prayers. The role of teachers in habituation prayer in congregation MTs $N$ is as educators, teachers, tutors, mentors, models and example, transfer camp, as well as generating the view.
\end{abstract}

Keywords: The role of teacher, habit of worship prayer, the worship congregation

\begin{abstract}
Abstrak
Tulisan ini merupakan hasil penelitian lapangan (field research) dengan menggunakan metode kualitatif. Tulisan ini berusaha untuk mengungkap tentangjenis ibadah sholat berjama'ah yang biasa dilakukan di Madrasah Tsanawiyah Negeri (MTs N) Galur Kulon Progo DIY, juga ingin menjelaskan tentang peran guru dalam membiasakan ibadah sholat berjama'ah bagi siswa di MTs N Galur Kulon Progo DIY. Dengan demikian pada kesimpulan tulisan ini menyebutkan bahwa jenis ibadah sholat berjama'ah yang biasa dilaksanakan di MTs $N$ Galur adalah sholat Dhuha, sholat Dhuhur, dan sholat Jum'at. Adapun Peran guru dalam pembiasaan sholat berjama'ah MTs $N$ Galur adalah sebagai pendidik, pengajar, pembimbing, penasehat, model dan teladan, pemindah kemah, serta pembangkit pandangan.
\end{abstract}

Kata Kunci: peran guru, pembiasan sholat, sholat berjama'ah

\section{PENDAHULUAN}

Ilmu pengetahuan dan teknologi yang berkembang dewasa ini membawa dampak positif dan negatif bagi masyarakat, terutama bagi anak-anak usia sekolah. Dampak positif bisa membawa perkembangan yang baik bagi anak-anak Indonesia. Mereka bisa menguasai teknologi, mengakses semua berita yang sedang terjadi di dunia. Penggunaan ilmu pengetahuan dan teknologi bagi sebagaian generasi muda yang belum sadar teknologi dan tidak mendapat pengawasan kadang membawa dampak negatif. Pengawasan bisa dilakukan oleh berbagai pihak. Di rumah mereka dapat dipantau oleh orang tua, sedangkan di sekolah guru berperan aktif yaitu mengawasi dan memantau siswa.

Menurut UU RI No. 20 tahun 2003 tentang Sisdiknas dan UU RI No 14 tahun 2005 tentang Guru dan Dosen, bab I pasal 1 yang dimaksud dengan: 
"Pendidikan adalah usaha sadar dan terencana untuk mewujudkan suasana belajar dan proses pembelajaran agar siswa secara aktif mengembangkan potensi dirinya untuk memiliki kekuatan spiritual keagamaan, pengendalian diri, kepribadian, kecerdasan, akhlak mulia, serta keterampilan yang diperlukan dirinya, masyarakat, bangsa, dan Negara."1

Dari uraian di atas dapat dijelaskan bahwa pendidikan merupakan usaha sadar dan terencana. Artinya dalam mendidik anak diperlukan unsur sengaja dan direncanakan, agar anak didik berakhlak mulia dan memiliki kekuatan spriritual keagamaan yang cerdas, kuat, dan mandiri.

Menanamkan keseimbangan koknitif, afektif, dan psikomotorik pada pribadi siswa melalui pembelajaran Pendidikan Agama Islam di kelas perlu proses dan waktu. Kenyataannya waktu yang diberikan oleh sekolah sangat terbatas. Sebagai inisiatif untuk menambah waktu pembelajaran keagamaan yang terbatas, ada beberapa sekolah yang mewajibkan siswanya untuk mengikuti sholat berjam'ah. Hal tersebut diterapkan agar siswa bisa menggunakan waktu luangnya dengan beribadah dan meningkatkan kedisiplinan diri. ${ }^{2}$

Misalnya di madrasah Tsanawiyah Negeri Galur yang memberikan tambahan jam pelajaran keagamaan, yang sifatanya praktis. Di MTs diterapkan tadarus di pagi hari sebelum mulai pembelajaran, melaksanakan sholat Dhuha berjama'ah, melaksanakan sholat Dhuhur berjamaah, dan hari Jum'at melaksanakan sholat Jum'at bagi siswa putra maupun putri. Bagi siswa putri apabila berhalangan melaksanakan sholat Jum'at, diadakan pelajaran keputrian yang dilaksanakan di dalam kelas. ${ }^{3}$

${ }^{1}$ Departemen Agama RI, Undang-Undang Republik Indonesia No 20 Tahun 2003 Tentang Sisdiknas serta Undang-Undang Republik Indonesia No 14 Tahun 2005 Tentang Guru dan Dosen (Jakarta, Depag: 2007) hlm, 2

${ }^{2}$ Siti Mahmudati, Kepala Sekolah, Wawancara tangga 17 April 2016

${ }^{3}$ Marwati, Guru Bahasa Inggris, Wawancara tanggal 25 April 2016
Pembiasaan sholat berjama'ah di MTs N Galur bertujuan untuk mendidik siswasiswanya agar mempunyai sifat taqwa kepada Sang Pencipta. Pengertian taqwa secara umum adalah menjalankan perintah-Nya dan menjauhi segala larangan-Nya. Pada kenyataanya masih ada siswa yang tidak melaksanakan ibadah berjama'ah jika tidak diingatkan, masih ada siswa yang terlambat shalat Dhuha.

Madrasah Tsanawiyah Negeri Galur Kabupaten Kulon Progo merupakan tempat penelitian yang dituangkan dalam tulisan ini”. Dalam tulisan ini hendak menganalisis apa saja sholat berjamaah yang di terapkan di MTs N Galur Kulon Progo? Dan bagaimana peran guru dan sekolah dalam membiasakan sholat berjamaah di MTs N Galur Kulon Progo? Untuk menganalisis dua persoalan tersebut, penulis menggunakan metode kualitatif (qualitative research) yaitu suatu penelitian yang bertujuan untuk mendiskripsikan dan menganalisis sikap, persepsi, pemikiran sesorang secara individu maupun kelompok, fenomena, peristiwa, aktifitas sosial, kepercayaan. ${ }^{4}$

\section{Peran Guru dalam Teori Pembelajaran}

Menurut Abin. S (1999) yang dikutip dalam bukunya Buchari Alma, terdapat beberapa tugas dan peran guru dalam proses pembelajaran, diantaranya: ${ }^{5}$

Pertama, guru sebagai pemelihara (konservator), yaitu guru memelihara sistem nilai yang merupakan sumber norma kedewasaan. Dalam sistem nilai pembelajaran, guru menjadi teladan bagi siswa untuk memelihara sistem nilai. Kedua, guru sebagai penerus (transmitor) sistem nilai, guru meneruskan dan mewariskan sistem-sistem nilai kepada siswa. Ketiga, guru sebagai penerjemah (transformator) artinya guru bertugas menerjemahkan sistem nilai tersebut melalui penjelmaan dalam pribadi dan perilakunya. Keempat, guru sebagai perencana (planner) artinya guru bertugas untuk

${ }^{4}$ Nana Syaodih Sukmadinata, Metode Penelitian Pendidikan (Bandung, Remaja Rosdakarya: 2011) hlm, 60

${ }^{5}$ Buchari Alma dkk, Guru Profesional Menguasai ..., hlm, 140 
mempersiapkan apa saja yang akan dilakukan dalam proses pembalajaran agar siswa dapat memahami apa yang telah diajarkan. Kelima, Guru sebagai proses pembelajaran (manajer), dalam proses pembelajaran guru mengelola proses operasional pembelajaran, mulai dari merencanakan, mempersiapkan, mengatur, menyelenggarakan, dan mengevaluasi proses pembelajaran. Keenam, guru sebagai pemandu (director). Dalam hal ini guru bertugas untuk menunjukkan arah tujuan pembelajaran siswa. Ketujuh, guru sebagai penyelenggara (organisator). Guru dalam hal ini bertugas mengorganisasikan seluruh kegiatan pembelajaran. Kedelapan, guru sebagai pengirim pesan (komunikator). Guru bertugas mengkomunikasikan kepada murid agar mereka akrab dengan berbagai sumber belajar. Kesembilan, guru sebagai fasilitator. Guru berperan memberi kemudahankemudahan kepada siswa untuk belajar dan memahami pelajaran. Kesepuluh, Guru sebagai pendorong (motivator). Guru bertugas memberi dukungan dan motivasi kepada siswa agar memiliki semangat untuk belajar yang tinggi. Kesebelas, guru sebagai penilai (evaluator). Guru sewajarnya untuk mengidentifikasikan, mengumpulkan, menganalisis, menafsirkan data yang valid, reliabel, dan objektif. Akhirnya guru dapat memberi pertimbangan terkait tingkat keberhasilan pembelajaran berdasarkan kriteria yang sudah ditetapkan.

Selain beberapa peran di atas, Enco Mulyasa juga memberi beberapa peran alternatif kepada guru dalam pembelajaran, diantaranya: ${ }^{6}$

\section{Guru sebagai pendidik}

Sewajarnya, guru sebagai pendidik mempunyai standar kepribadian mandiri, disiplin, tanggung jawab, dan berwibawa. Berkaitan dengan mandiri, seorang guru bisa mengambil keputusan dan bertindak dengan cepat, tepat waktu, dan tepat sasaran, terutama dalam masalah pembelajaran dan peserta didik. Berkaitan dengan disiplin, seorang guru harus

\footnotetext{
${ }^{6}$ Mulyasa, Menjadi Guru Profesional Menciptakan Pembelajaran Kreatif dan Menyenangkan (Bandung, Remaja Rosdakarya: 2006) hlm, 36-64
}

mematuhi berbagai peraturan secara konsisten dan dengan kesadaran professional. Para guru bertugas mendisiplinkan siswanya, yang dimulai dari diri guru itu sendiri. Berkaitan dengan tanggung jawab, guru bertanggung jawab pada tindakannya baik di sekolah maupun dalam kehidupan bermasyarakat. Berkaitan dengan wibawa, dalam merealisasikan nilai-nilai spritual, sosial, emosi, intlektual dan moralnya, guru hendaknya memiliki kelebihan. Begitu juga dalam pemahaman ilmu pengetahuan dan teknologi hendaknya sesuai dengan bidang yang dikembangkannya.

\section{Guru sebagai pengajar}

Tugas utama seorang guru adalah mengajar, memberikan berbagai materi yang belum dipahami siswa, dan sebagainya. Kegiatan belajar siswa akan berjalan baik, apabila faktor motivasi, kematangan, hubungan siswa dengan guru, kemampuan verbal, rasa aman, dan ketrampilan guru berkomunikasi berjalan dengan baik.

\section{Guru sebagai pembimbing}

Sebagai pembimbing, guru merumuskan tujuan dengan jelas akan dibawa kemana siswasiswanya agar menjadi generasi muda harapan bangsa.

\section{Guru sebagai pelatih}

Sebagai pelatih, guru bertugas melatih peserta didik dalam pembentukan kompetensi dasar sesuai dengan potensi yang ada pada diri peserta didik.

\section{Guru sebagai penasehat}

Banyak siswa mengadu kepada guru sebagai orang kepercayaannya. Secara otomatis guru tersebut akan memberikan nasihat kepada siswanya. Agar bisa menjadi seorang penasihat yang baik, seorang guru harus memahami psikologi kepribadian dan ilmu kesehatan mental.

\section{Guru sebagai pembaharu (innovator)}

Guru bertugas menerjemahkan pengalaman yang telah lalu ke dalam kehidupan yang bermakna bagi peserta didik. Seorang peserta didik yang belajar sekarang secara psikologis 
berada jauh dari pengalaman manusia yang harus dipahami, dicerna, dan diwujudkan dalam pendidikan. Guru sebagai penjebatan jurang ini bagi peserta didik, jika tidak, peserta didik tidak akan menggunakan potensi yang dimilikinya. Tugas guru adalah memahami bagaimana keadaan jurang pemisah ini dan bagaimana cara untuk menjembataninya secara efektif.

Prinsip era modern tidak hanya diwujudkan dalam bentuk buku-buku sebagai alat utama pendidikan, tetapi semua rekaman tentang pengalaman manusia juga bisa dijadikan sebagai alat pendidikan. Guru bertugas menerjemahkan kebijakan dan pengalaman yang berharga ke dalam istilah atau bahasa modern yang mudah diterima oleh peserta didik. Oleh karena itu, sebagai jembatan antara generasi tua dan generasi muda, dan juga sebagai penerjemah pengalaman. Guru harus menjadi pribadi yang terdidik.

\section{Guru sebagai model dan teladan}

Menjadi teladan merupakan sifat dasar kegiatan pembelajaran. Sebagai teladan, tentu saja pribadi dan apa saja yang dilakukan guru akan mendapat sorotan peserta didik dan orang sekitarnya. Contoh aspek tingkah laku yang menjadi sorotan dan perlu didiskusikan para guru adalah sikap dasar pribadi, bicara dan cara bicara, kebiasaan bekerja, sikap melalui pengalaman dan kesalahan, pakaian, hubungan kemanusiaan, proses berpikir, perilaku neorotis, selera, keputusan, kesehatan, dan gaya hidup secara umum.

Menjadi teladan merupakan bagian integral dari para guru, sehingga guru berarti menerima tanggung jawab untuk menjadi teladan. Meskipun sebagai manusia biasa, guru memiliki kelemahan dan kekurangan.

\section{Guru sebagai pribadi}

Guru yang baik harus memiliki kepripadian yang mencerminkan seorang pendidik. Guru sering dijadikan panutan oleh masyarakat, oleh karena itu guru harus mengenal nilai-nilai yang dianut dan berkembang di masyarakat. Ujian terberat bagi guru adalah rangsangan yang bisa memancing emosinya. Seorang guru harus bisa menjaga kestabilan emosi, maka dari itu upaya dalam bentuk latihan mental sangat diperlukan. Pematangan emosi guru akan berkembang sejalan dengan pengalaman bekerja, selama dia mau memanfaatkan pengalamannya.

Sebagai pribadi yang hidup di tengahtengah masyarakat. Guru juga harus memiliki kemampuan untuk berbaur di masyarakat, sebab kalau tidak pergaulannya akan menjadi kaku dan kurang bisa diterima di masyarakat. Dalam pergaulan, guru diamati dan dinilai oleh masyarakat, sedangkan di sekolah guru diamati oleh peserta didik dan teman sejawatnya serta atasannya. Sebaiknya seorang guru minta pendapat teman sejawat atau peserta didik tentang penampilannya sehari-hari untuk dapat memperbaiki penampilan tertentu yang kurang tepat.

\section{Guru sebagai peneliti}

Kebutuhan untuk mengetahui merupakan kebutuhan semua manusia. Guru yang menyadari bahwa ia tidak mengetahui sesuatu, maka ia berusaha mencarinya melalui kegiatan penelitian. Menyadari akan kekurangannya, seorang guru harus berusaha mencari apa yang belum diketahui untuk meningkatkan kemampuannya dalam melaksanakan tugas.

\section{Guru sebagai pendorong}

Kreativitas guru yang kreatif menyadari bahwa kreativitas bersifat universal. Semua kegiatannya ditopang, dibimbing, dan dibangkitkan oleh kesadaran itu. Oleh karena itu, guru selalu berusaha menemukan cara yang lebih baik dalam melayani peserta didik, sehingga mereka akan menilai bahwa guru mereka memang kreatif.

\section{Guru sebagai pembangkit pandangan}

Sebagai seorang pembangkit pandangan, seorang guru dituntut untuk dapat memberikan dan memelihara pandangan tentang keagungan Sang Pencipta kepada peserta didiknya. Guru harus dibekali dengan ajaran tentang hakikat manusia dan setelah mengenalnya akan mengenal pula kebesaran Allah yang menciptakannya. Guru harus mampu menanamkan pandangan 
positif terhadap martabat manusia ke dalam pribadi peserta didik. Peserta didik diharapkan bisa menjadi orang yang menjunjung tinggi harkat dan martabat manusia, sehingga terjadi kehidupan bermasyarakat yang sejahtera lahir batin.

\section{Guru sebagai evaluator}

Evaluator atau penilaian sifatnya sangat kompleks. Mengingat hal tersebut, seorang guru harus memiliki pengetahuan, keterampilan, dan sikap yang memadai. Sebagai seorang evaluator, seorang guru harus memahami teknik evaluasi, baik tes maupun non-tes yang meliputi berbagai teknik, karakteristik, prosedur pengembangan, serta cara menentukan baik atau tidaknya ditinjau dari berbagai segi, validitas, reliabilitas, daya beda, dan tingkat kesukaran soal.

Berdasarkan uraian di atas, menunjukkan bahwa peran guru sangatlah penting. Profesi guru merupakan salah satu profesi yang mulia, walaupun ada sebagian yang memandang profesi guru masih dipandang sebagai profesi yang paling rendah. Hal tersebut disebabkan beberapa faktor. Faktor pertama disebabkan beberapa masyarakat berpandangan bahwa siapapun bisa menjadi guru asal ia mempunyai pengetahuan, misalnya di daerah terpencil, siapapun yang mempunyai pengalaman bisa menjadi guru. Faktor yang kedua disebabkan guru itu sendiri. Banyak sebagian guru yang tidak menghargai profesinya, merasa rendah diri dan melaksanakan kepentingan pribadinya. ${ }^{7}$

\section{Sekilas Tentang MTs Negeri Galur Kulon Progo}

Madrasah Tsanawiyah Negeri Galur merupakan lembaga pendidikan formal di bawah naungan Kementrian Agama Republik Indonesia. Secara geografis letaknya sangat strategis yakni di Dusun Klampok, Desa Brosot, Kecamatan Galur, Kabupaten Kulon Progo. Madrasah ini dibangun di atas lahan seluas $4.366 \mathrm{~m}^{2}$. Letak MTs Negeri Galur ini berada di sebelah Utara jalan raya Brosot kurang lebih

\footnotetext{
${ }^{7}$ Nana Sudjana, Dasar-Dasar Proses Belajar Mengajar, (Bandung, Sinar Baru Algensindo: 2010), hlm. 14
}

$50 \mathrm{~m}^{2}$ ke Barat dari Kecamatan Galur masuk ke Utara sekitar $25 \mathrm{~m}^{2}$. Madrasah ini berlokasi di tengah-tengah pemukimam penduduk yang masih kondusif. Batas geografis Madrasah Tsanawiyah Negeri Galur diantaranya, sebelah Barat berbatasan dengan rumah warga. Sebelah Timur berbatasan dengan rumah warga. Sebelah Selatan berbatasan dengan kebun warga. Sebelah Utara berbatasan dengan SD Asrama Muhammadiyah Brosot.

MTs N Galur ada di Desa Brosot, Galur, Kulon Progo, Daerah Istimewa Yogyakarta dan berdiri pada 1975, kemudian mengalami perubahan pada 1997. Perjalanan perubahan madrasah berlangsung sejak 1975 sampai 1977, yang semula bernama MTs LKMD. Pada tahun 1997 mengalami perubahan menjadi MTS Negeri. Pada saat ini bangunan gedung sudah milik sendiri. Kegiatan belajar mengajar dilaksanakan pada pagi hari. Sekarang madrasah ini sudah terakreditasi A.

Menurut Peraturan Menteri Pendidikan Nasional (Permendiknas) No. 19 Tahun 2007, tentang Standar Pengelolaan Pendidikan oleh Satuan Pendidikan Dasar dan Menengah, yang mencantumkan beberapa tujuan diantaranya adalah: ${ }^{8}$ (1) Menggambarkan tingkat kualitas yang perlu dicapai dalam jangka menengah (empat tahunan), (2) Mengacu pada visi, misi, tujuan pendidikan nasional, dan relevan dengan kebutuhan masyarakat, (3) Mengacu pada standar kompetensi lulusan yang sudah ditetapkan oleh sekolah/madrasah dan Pemerintah, (4) Mengakomodasi masukan dari berbagai pihak yang berkepentingan termasuk komite sekolah/madrasah dan diputuskan oleh rapat dewan pendidik yang dipimpin oleh kepala sekolah/madrasah, dan (5) Disosialisasikan kepada warga sekolah/madrasah dan segenap pihak yang berkepentingan."

Berdasarkan acuan dari Permendiknas tersebut di atas, MTs N Galur mempunyai tujuan sebagai berikut: (1) Seluruh warga madrasah memiliki keimanan dan ketakwaan yang mantap sebagai landasan berperilaku dalam

\footnotetext{
${ }^{8}$ Peraturan Menteri Pendidikan Nasional Republik Indonesia No 19 tahun 2007, Standar Pengelolaan Pendidikan, (Jakarta : 2007) hlm. 7
} 
kehidupan sehari-hari, (2) mewujudkan warga madrasah yang berkarakter mulia dan peduli pada lingkungan, (3) mempersiapkan para peserta didik untuk mengikuti pendidikan lebih lanjut, (4) mewujudkan inovasi pembelajaran yang efektif, kreatif dan efisien guna mencapai keunggulan prestasi, baik di bidang akademik maupun non-akademik, (5) guru dan siswa mampu menguasai ilmu pengetahuan, teknologi informasi, dan komunikasi, (6) meningkatkan keterampilan para siswa melalui pendidikan kecakapan hidup (life skill), (7) memiliki sarana dan prasarana yang memenuhi standar. (8) mampu melaksanakan pengelolaan pendidikan yang standar, (9) memiliki sistem penilaian yang sesuai standar, (8) Memiliki dana yang memadai untuk pengembangkan pendidikan.

\section{Pelaksanaan Sholat Berjama'ah di MTs N Galur}

"Visi MTs N Galur adalah akan menjadikan madrasah yang cerdas, agamis, normatif, terampil, inovatif, kreatif (CANTIK) dan berwawasan lingkungan. Oleh karena itu untuk mewujudkan visi tersebut MTs $N$ Galur berusaha keras untuk menjadikan peserta didiknya agar menjadi insan yang cerdas, dalam bidang pendidikan, agamis dalam menjalankan agama yang dianutnya, mempunyai norma dalam beragama, terampil dalam kehidupan bermasyarakat, banyak berinovasi, dan kreatif"'

Dalam rangka mewujudkan visi tersebut, MTs N Galur selain unggul dalam bidang pengetahuan, juga menanamkan nilai-nilai keagamaan yang sangat kuat bagi peserta didiknya. Tujuannya adalah meningkatkan keimanan dan norma-norma, baik norma agama maupun norma yang ada di masyarakat untuk hari depannya kelak.

Penanaman nilai agama yang diterapkan di MTs N Galur adalah pembiasaan sholat berjamaah. Secara bahasa sholat itu bermakna doa. Adapun makna shalat menurut syariah adalah serangkaian ucapan dan gerakan tertentu yang dimulai dengan

${ }^{9}$ Siti Mahmudati, Kepala Madrasah, Wawancara tanggal 25 April 2016 takbir, dan diakhiri dengan salam sebagai sebuah ibadah yang bersifat ritual. ${ }^{10}$

Shalat diwajibkan bagi umat Islam sepanjang zaman. Kewajiban shalat mutlak untuk semua orang yang beragama Islam, dan sudah akil baligh. Peserta didik usia remaja setingkat MTs adalah masa mencari jati dirinya. Oleh karena itu sangat disarankan penanaman nilai-nilai agama melalui sholat berjamaah. Sholat berjama'ah yang di terapkan di MTs N Galur adalah shalat Dhuha, Shalat Dzuhur, dan Shalat Jum'at.

\section{Sholat Dhuha}

MTs N Galur melaksanakan sholat Dhuha pada pagi hari jam 06.45 WIB sebanyak empat rakaat. Sambil menunggu imam datang sebelum melaksanakan sholat Dhuha, pada pukul 06.30 WIB diadakan tadarus di mushola. Sholat Dhuha pada Selasa dipimpin oleh Bapak Hendarto. Beliau adalah seorang guru mata pelajaran fiqih. Setelah beliau hadir di musholla, para siswa yang tadinya masih belum wudhu, segera menuju tempat wudhu dan bergantian. Para siswa harus diperingatkan agar segera melaksanakan sholat Dhuha.

Siswa yang terlambat masuk sekolah tentu saja terlambat melaksanakan sholat Dhuha. Siswa tersebut tetap harus melaksanakan sholat Dhuha sendiri sebanyak 8 rakaat. Sholat Dhuha berjama'ah di MTsN Galur dilaksanakan tiap pagi dan diikuti oleh semua siswa. Setelah melaksanakan shalat Dhuha, dilajutkan dengan membaca ayat kursi, doa setelah sholat dhuha, dan membaca juz'ama. Setelah selesai sholat Dhuha secara berjamaah, peserta didik masuk kelas dan dilanjutkan dengan tadarus di dalam kelas.

Kegiatan sholat Dhuha setiap hari didampingi oleh guru pendamping secara bergantian yang telah ditetapkan jadwalnya. Pembiasaan sholat berjamaah sebetulnya merupakan ibadah yang wajib di MTs N Galur. Ibadah sholat berjamaah sudah tercantum dalam tata tertib siswa di MTs N Galur tahun ajaran 2015/2016 yaitu: ${ }^{11}$

\footnotetext{
${ }^{10}$ Syaikh Dr. Shalih bin Fauzan, Fiqih Shalat, (Yogyakarta, Mumtaz : 2011) hlm. 1

${ }^{11}$ Dokumentasi MTs N Galur tahun ajaran
} 
"Setiap Siswa wajib, (1) mengikuti upacara bendera (2) mengikuti kegiatan intrakurikuler dengan ketentuan sebagai berikut: (a) Siswa mulai masuk jam 07.00 WIB, selambatlambatnya 30 menit sebelum kegiatan belajar mengajar dimulai semua siswa harus sudah datang di Madrasah untuk melaksanakan shalat Dhuha.(b) Selama istirahat semua siswa berada di luar kelas.(c) Selama mengikuti pelajaran, siswa berada di dalam kelas dengan tertib dan tenang. (d) Sebelum memulai dan mengakhiri pelajaran semua siswa berdo'a dengan khidmat dan terpimpin. (e) Setelah 5 menit jam pelajaran dimulai, bapak/ibu guru belum hadir ketua kelas lapor pada guru piket. (f) Apabila guru berhalangan hadir, siswa menghubungi guru piket untuk minta tugas, (g) siswa yang terlambat datang minta izin pada guru piket/guru BK untuk mengikuti pelajaran (dengan surat izin), (h) siswa yang berhalangan masuk sekolah harus ada pemberitahuan atau surat ijin orang tua/wali, (i) menyelesaikan tugas sekolah dengan tepat waktu, (j) masuk sekolah dan belajar sesuai kalender pendidikan. (k) siswa wajib mengikuti jama'ah Dhuhur dan sholat Dhuha. (1) siswa wajib menjadi anggota perpustakaan."

\section{Sholat Dhuhur}

Shalat Dhuhur dikerjakan pada waktu zawalus syamsi yaitu waktu di mana posisi matahari ada di atas kepala kita, namun sedikit sudah mulai bergerak ke arah Barat. Jadi, tidak tepat di atas kepala. ${ }^{12}$ Pelaksanaan sholat Dhuhur berjama'ah di MTsN Galur diikuti oleh semua siswa dan guru. Pelaksanaannya pada istirahat kedua, yaitu pada pukul 12.00 WIB. Sebelum melaksanakan sholat Dhuhur berjama'ah, semua siswa mengadakan tadarus juz 'amma yang dipimpin oleh ketua Organisasi Siswa Intra Sekolah (OSIS). Setelah melaksanakan sholat Dhuhur, semua jamaah mengadakan sholat ba'diyah dua rakaat. Untuk siswa putri yang sedang berhalangan atau tidak sholat, ada absen per kelas.

\footnotetext{
$2015 / 2016$

${ }^{12}$ Syaikh Dr. Shalih bin Fauzan, Fiqih Shalat..., hlm, 28
}

Setelah melaksanakan shalat Dhuhur, ada siswa yang kami wawancarai mengatakan bahwa:

"Sholat Dhuhur berjama'ah wajib di madrasah ini. Sholat berjama'ah pahalanya lebih banyak daripada sholat sendiri. Anak-anak sudah terbiasa melakukannya begitu mendengar bel istirahat ke dua langsung pada ke musholla"13

\section{Sholat Jum'at}

Shalat Jum'at disyariatkan di dalam AlQur'an, As-Sunnah an Nabawiyah dan juga oleh Ijma' seluruh ulama. ${ }^{14}$ Pensyariatan oleh AlQuran disebutkan dalam surat Al-Jumuah ayat 9. Allah telah mewajibkan umat Islam untuk melaksanakan shalat Jum'at sebagai bagian dari kewajiban atau fardhu 'ain atas tiap-tiap muslim yang memenuhi syarat. Pensyariatan oleh asSunnah, disebutkan oleh Thariq bin Syihab ra, bahwa Rasulullah bersabda:

"Shalat Jum'at itu adalah kewajiban bagi setiap muslim dengan berjama'ah, kecuali (tidak diwajibkan) atas 4 orang yaitu: budak, wanita, anak kecil, dan orang sakit." (HR. Abu Daud)

Pelaksanaan khutbah sholat jum'at di MTsN Galur dimulai jam 11.50 WIB dan diawali dengan tadarus. Imam otomatis menjadi khatib. Dalam pelaksanaan sholat jum'at di MTsN Galur telah terjadwal dengan tertib.

\section{Peran Guru dalam Pembiasaan Sholat Berjama'ah}

Peran guru dalam membiasakan sholat berjama'ah di MTs N Galur memegang peran penting, sebagaimana dalam buku Nana Sujana yang mengatakan bahwa bagaimanapun kehadiran guru dalam proses belajar mengajar atau pengajaran masih tetap memegang peranan penting. ${ }^{15}$ Kehadiran dalam hal ini adalah bentuk secara nyata yang dicontohkan guru baik gerakan

\footnotetext{
${ }^{13}$ Arifah Mulyani, siswa kelas VIIIB, wawancara tanggal 16 Mei 2016 hlm, 160

${ }^{14}$ Syaikh Dr. Shalih bin Fauzan, Fiqih Shalat...,

${ }^{15}$ Nana Sujana, Dasar-dasar Proses..., hlm,12
} 
maupun ucapan. Sementara itu menurut Undangundang Guru dan Dosen, guru adalah guru profesional dengan tugas utama mendidik, mengajar, membimbing, mengarahkan, melatih, menilai, dan mengevaluasi peserta didik pada pendidikan usia dini, jalur pendidikan formal, pendidikan dasar, dan pendidikan menengah. ${ }^{16}$ Sedangkan menurut E. Mulyasa, ada beberapa peran guru dalam pembelajaran, antara lain : guru sebagai pendidik, guru sebagai pengajar, guru sebagai pembimbing, guru sebagai pelatih, guru sebagai penasehat, guru sebagai innovator, guru sebagai pembangkit pandangan, dan sebagainya. ${ }^{17}$

Dalam penelitian ini peneliti tidak hanya mewawancarai guru agama saja. Pada dasarnya peran semua guru sangat diperlukan dalam penanaman nilai-nilai agama dan moral bagi peserta didik. Seorang guru yang baik telah mempunyai beberapa kompetensi yaitu kompetensi personal, kompetensi sosial, kompetensi profesional, dan kompetensi pedagogik. Kompetensi personal menyangkut pribadi guru yang tercermin dalam kehidupan sehari-hari. Seorang guru haruslah berpenampilan yang baik dan sopan agar bisa dijadikan teladan atau contoh oleh peserta didiknya.

Setelah melakukan penelitian di MTs $\mathrm{N}$ Galur, dengan berdasarkan landasan teori tersebut di atas, terdapat beberapa peran guru dalam pembiasaan ibadah sholat berjamaah kelas VIII di MTs N Galur. Adapun peran guru tersebut antara lain: pendidik, pengajar, pembimbing, pelatih, penasehat, model dan teladan, serta pembangkit pandangan.

\section{Pendidik}

Guru sebagai seorang pendidik, tentunya mempunyai standar kualitas pribadi yang mencakup tanggung jawab, wibawa, mandiri, dan disiplin. Menurut pengamatan peneliti di MTs N Galur, tanggung jawab guru untuk mendidik peserta didiknya agar menjadi manusia yang lebih baik sangat besar. Pembiasaan sholat berjama'ah merupakan salah satu bentuk

${ }^{16}$ Departemen Agama RI, Undang-undang Republik Indonesia ..., hlm,59 hlm, 36-64

${ }^{17}$ E. Mulyasa, Menjadi Guru Profesional..., tanggung jawab seorang guru. Peserta didik juga dididik untuk disiplin.

"Setiap pagi begitu bel berbunyi, anakanak langsung menuju musholla untuk melaksanakan sholat Dhuha berjama'ah" 18

Sholat berjama'ah mengajarkan peserta didik agar menjadi seorang pemimpin. Hal tersebut tergambar dengan siswa diberi tugas untuk menjadi mu'adzin dalam sholat Jum'at dengan digilir secara terjadwal.

\section{Pengajar}

Tugas utama seorang guru adalah memberi pengajaran tentang materi-materi yang belum dipahami oleh peserta didik. Di MTs N Galur, guru selain mengajarkan tentang ilmu pengetahuan umum, tentu saja mengajarkan tentang ilmu agama Islam baik terkait tatacara sholat dan berjama'ah. Keseluruhan guru memberi pembelajaran pada anak-anak bagaimana melaksanakan ibadah sholat yang benar, baik terkait gerakan sholat (rukun fi'liyah) yang benar maupun bacaan sholat (rukun qouliyah) yang belum benar. Hal ini dipertegas oleh salah seorang siswa kelas 8 Shafira Novitarini:

"Untuk surat-surat pendek dan ayat-ayat al Qur'an yang belum benar, guru mengajarkan bagaimana seharusnya bacaan tersebut dibaca dan gerakan-gerakan sholat yang benar, tetapi kalau untuk niat, pihak madrasah atau sekolah menyerahkan pada masing-masing siswa, karena ada perbedaan pandangan di kalangan terkait niat tidak harus dilafadzkan dan niat harus dilafadzkan"'19

Guru Fiqih terutama, mengajarkan tentang keutamaan sholat berjam'ah daripada sholat sendiri.

\section{Pembimbing}

Sebagai seorang pembimbing, tentu saja para guru di MTs N Galur senantiasa

${ }^{18}$ Shafira Novitarini, Siswa kelas VIIIB, wawancara tanggal 16 Mei 2016

${ }^{19}$ Tatik.R, Guru Agama Mts N Galur, wawancara tanggal 16 Mei 2016 
mengarahkan peserta didiknya agar menjadi manusia yang lebih baik. Peserta didik dibimbing untuk melaksanakan sholat secara berjama'ah. Siswa dibimbing untuk segera melaksanakan sholat dan tidak menundanunda kewajibannya. Ketika di sekolah, guru senantiasa mengajak siswa untuk sholat pada waktunya dan berjama'ah. ${ }^{20}$

\section{Pelatih}

Sebagai seorang pelatih, guru bertugas untuk melatih peserta didik dalam pembentukan kompetensi dasar dan menggali potensi yang ada pada diri peserta didik. Hal ini tampak jelas ketika peserta didik dilatih oleh guru untuk mengisi khutbah Jum'at. ${ }^{21}$

\section{Penasehat}

Guru sebagai penasehat akan memberikan nasehat yang baik pada peserta didik. Guru harus memahami psikologi kepribadian dan ilmu kesehatan mental. Berdasarkan hasil wawancara dengan Ibu Supiyati selaku guru Bimbingan dan Konseling,

"Peserta didik yang terlambat tidak akan dimarahi, tetapi dinasehati, kemudian disuruh sholat Dhuha sendiri 8 rekaat. Setelah melaksanakan sholat, anak tersebut ditanya apa masalah yang sedang dihadapi, kemudian disarankan untuk Istighfar $100 \mathrm{kali}$, membaca Al-Fatihah, al-Ikhlas, Al-Falaq, An-Naas, dan ayat Kursi agar anak tersebut tenang" 22

\section{Model dan Teladan}

Sebagai model dan teladan bagi peserta didik, seorang guru harus menunjukkan sikapsikap yang terpuji dan bisa dijadikan panutan oleh peserta didik. Hal ini terpancar dari para guru yang ada di MTs N Galur, dengan senyum dan sopan, mereka memberi contoh dan sesekali mengajak peserta didik yang tidak menyegerakan melaksanakan sholat berjama'ah. ${ }^{23}$

\footnotetext{
${ }^{20}$ Observasi Rabu, 18 Mei 2016

${ }^{21}$ Observasi Jum'at, 13 Mei 2016

${ }^{22}$ Supiyati, Guru Bimbingan Konseling di MTs

N Galur, wawancara tanggal 16 Mei 2016

${ }^{23}$ Observasi Jum'at, 20 Mei 2016
}

\section{Pembangkit Pandangan}

Sebagai pembangkit pandangan, seorang guru harus bisa meyakinkan peserta didik bahwa Tuhan Yang Maha Kuasa adalah satusatunya Sang Pencipta yang wajib disembah. Oleh karena itu ibadah sholat berjamaah sangat tepat diterapkan dalam rangka membentuk keyakinan tersebut.

Menurut Kepala Madrasah, peran guru di MTs N Galur meliputi:

Sebagai fasilitator: memberi kesempatan siswa untuk berperan dalam proses pembiasaan berjamaah seperti menjadi muazin, menggantikan imam, bila bapak guru berhalangan hadir atau sedang tugas luar.

Sebagai motivator: memberi dorongan keaktifan siswa dalam berjamaah, dan memberi pengertian manfaat berjamaah.

Sebagai pembina: mengarahkan ketertiban, kebenaran, dalam melaksanakan sholat, wudhu, dan lain-lain. ${ }^{24}$

\section{KESIMPULAN}

Berdasarkan hasil penelitian tentang peran guru dan sekolah dalam pembiasaan sholat berjama'ah siswa kelas VIII MTsN Galur, Kulon Progo, maka peneliti mengambil kesimpulan sebagai berikut.

Sholat berjama'ah yang dilakukan oleh siswa kelas VIII MTs N Galur adalah sholat Dhuha, sholat Dhuhur, dan sholat Jum'at

Peran guru dalam pembiasaan sholat berjama'ah MTs N Galur adalah sebagai pendidik, pengajar, pembimbing, penasehat, model dan teladan, pemindah kemah, serta pembangkit pandangan. Peran Guru sangat penting, karena tanpa guru peserta didik tidak akan melaksanakan pembiasaan ibadah sholat berjamaah. Peran sekolah juga sangat banyak. Sekolah memfasilitasi tempat wudhu dan tempat ibadah yaitu musholla yang luas dan bersih. Visi sekolah dan tata tertib siswa juga mendukung terciptanya peserta didik yang agamis.

${ }^{24}$ Siti Mahmudati, Kepala Madrasah, Wawancara tanggal 25 April 2016

LITERASI, Volume VIII, No. 12017 


\section{DAFTAR PUSTAKA}

Abdul Kadir dkk, 2012, Dasar-Dasar Pendidikan, Kencana Prenadamedia, Jakarta.

Abuddin Nata, 1998, Metodologi Studi Islam, Raja Grafindo Persada, Jakarta.

Ahmad Salim, 2013, Manajemen Pendidikan di Madrasah, Sabda Media, Yogyakarta.

Ahmad Taufiq dan Muhammad Rohmadi, 2010, Pendidikan Agama Islam Pendidikan Karakter Berbasis Agama, Yuma Pustaka, Surakarta.

Aliy As'ad, 1980, Terjemah Fat-Hul Mu'in, Menara Kudus, Kudus.

Ashadi dan Cahyo Yusuf, 2000, Akhlak Membentuk Pribadi Muslim, Aneka Ilmu, Semarang.

Binti Maunah, 2009, Ilmu Pendidikan, Teras, Yogyakarta

D.B.Mirchandani, 2010, Al-Qur'anku (Tata cara Pembacaan Alqur'an dengan kode Warna yang di blok), Lautan Lestari, Jakarta.

Departemen Agama Republik Indonesia, 2007, Undang-undang Republik Indonesia No 20 tahun 2003 tentang Sisdiknas serta Undang-undang Republik Indonesia No 14 tahun 2005 tentang Guru dan Dosen, Depag, Jakarta.

H.A. Djazuli, 2010, Ilmu Fiqih Penggalian, Perkembangan, dan Penerapan Hukum Islam, Kencana, Jakarta.

H.M.Sudiyono, 2009, Ilmu Pendidikan Islam, Rineka Cipta, Jakarta.

Ibnu Rif'ah Ash-Shilawy, 2009, Panduan Lengkap Ibadah Shalat, Citra Risalah, Yogyakarta.

Jalaludin dan Abdullah Idi, 2010, Filsafat Pendidikan, Remaja Rosdakarya, Bandung.

Jufry al Hazza, 2013, Tuntunan Shalat Sunnah, Uba Press, Jakarta.

M.A. Subandi, 2013, Psikologi Agama dan Kesehatan Mental, Pustaka Pelajar, Yogyakarta.

Muchlas Samani dan Drs.Hariyanto,M.S, 2011, Konsep dan Model Pendidikan Karakter, Remaja Rosdakarya, Bandung.
Mulyasa, 2006, Menjadi Guru Profesional Menciptakan Pembelajaran Kreatif dan Menyenangkan, Remaja Rosdakarya, Bandung.

Moh. Rifa'I. 1998, Risalah Tuntunan Shalat Lengkap, Toha Putra, Semarang.

Mohammad Daud Ali, 2011, Pendidikan Agama Islam, Rajawali Pers, Jakarta.

Nana Sujana. 2010, Dasar-Dasar Proses Belajar Mengajar, Sinar Baru Algensindo, Bandung.

Musnid bin Muhsin Al-Qothoni, 2006, Seindah Sholat Berjamaah, Al-Qowam, Solo.

Nana Syaodih Sukmadinata, 2011, Metode Penelitian Pendidikan, Remaja Rosdakarya, Bandung.

Nasution, 2014, Sosiologi Pendidikan, Bumi Aksara, Jakarta.

Nur Kolis, 2003, Management Berbasis Sekolah, Grasindo, Jakarta.

Oemar Hamalik, 2012, Psikologi \& Mengajar, Sinar Baru Algensindo, Bandung.

Sugiyono, 2013, Metode Penelitian Pendidikan Pendekatan Kuantitatif, Kualitatif, dan $R \& D$, Alfabeta, Bandung.

Suharsimi Arikunto, 2008, Prosedur Penelitian Suatu Pendekatan Praktek Edisi Revisi V, Rineka Cipta, Jakarta.

Syaiful Bahri Djamarah dan Aswan Zain, 2010, Strategi Belajar Mengajar, Rineka Cipta, Jakarta.

Syaikh Dr. Shalih bin Fauzan, 2011, Fiqih Shalat, Mumtaz, Yogyakarta.

Thomas Lickona, 2013, Pendidikan Karakter Panduan Lengkap Mendidik Siswa Menjadi Pintar dan Baik, Nusa Media, Bandung.

Uyoh Sadulloh dkk, 2011, Pedagogik (Ilmu Mendidik), Alfabeta, Bandung.

W.J.S. Poerwadarminta, 2007, Kamus Umum Bahasa Indonesia, Balai Pustaka, Jakarta.

Wina Sanjaya, 2006. Strategi Pembelajaran Berorientasi Standar Proses Pendidikan. Jakarta. Kencana Prenadamedia Group.

Wina Sanjaya, 2011, Strategi Pembelajaran Berorientasi Standar Pendidikan, Kencana, Jakarta. 